\title{
Research on the Construction of Teaching Evaluation System of Visual Communication Design Major Cultivated on Basis of Students' Innovation and Entrepreneurship Ability
}

\author{
Yongxiao Liu
}

\author{
Baoshan University, Baoshan, China \\ *Corresponding author. Email:314320737@qq.com
}

\begin{abstract}
As an undergraduate major concerning art design in the colleges and universities, visual communication design is a very strong one in terms of applicability during the education of the colleges and universities. It requires students to have a more systematic professional theory, knowledge and design ability, and focuses on the cultivation of students' design ability, language communication, written and verbal expression, social communication and other comprehensive abilities to ultimately cultivate comprehensive design talents suitable for social and economic development, and enable students to adapt to the requirements of the society for the major after graduation, and better improve their employability and competitiveness.. Therefore, colleges and universities that have this major actively improve the reform of teaching mode and teaching evaluation system, and deepens the improvement of teaching evaluation system comprehensively, which aims to cultivate and enhance students' innovation and entrepreneurship ability, thereby cultivating high-quality comprehensive innovation and entrepreneurship talents. Based on the existing problems of innovation and entrepreneurship education, this paper analyzes how to build a good evaluation system of innovation and entrepreneurship education. Combined with the analysis of the actual situation, it provides a feasible theoretical reference for the construction of the teaching evaluation system regarding its visual communication design, so as to achieve the training goal of innovation and entrepreneurship talents.
\end{abstract}

Keywords: Innovation and entrepreneurship ability, visual communication design, teaching evaluation

system, and university teaching reform

Under the background of national "innovation and entrepreneurship", colleges and universities across the country are also actively carrying out innovation and entrepreneurship education, making the cultivation of students' innovation and entrepreneurship ability like mushrooms after rain. It is the core of higher education to cultivate the comprehensive high-quality talents. The main competitiveness of higher education depends on whether graduates can perfectly adapt to the society. The innovation and entrepreneurship education is relatively perfect after developing for a long time in the United States. However, our innovation and entrepreneurship education is still in the stage of exploratory and embryonic domestically, which will take a long time to get good development and experience accumulation. At present, innovation and entrepreneurship education still does not have a good teaching evaluation system, and the key task of the current education reform lies in deepening comprehensively the evaluation system of innovation and entrepreneurship teaching in colleges and universities. It is also a new and challenging field in China. Compared with other majors in Colleges and universities, the visual communication design major is more special, needing higher requirements for application and practice Therefore, it is more convenient and easier to carry out education in innovation and entrepreneurship and reform the existing teaching mode. Nowadays, colleges and universities are trying to change the traditional education concept and improve the teaching evaluation system of visual communication design so as to improve students' innovation and entrepreneurship ability [1].

\section{THE IMPORTANCE OF PERFECT TEACHING EVALUATION SYSTEM}

With the continuous development of the society and the continuous reform of the teaching system, the teaching results will have been naturally altered. A perfect and excellent teaching evaluation system can intuitively show both the teaching level of teachers and the problems of students. The basis and strategic guidelines of the quality of innovation and entrepreneurship education in Colleges and universities depend on the teaching evaluation system with the guidance of scientific theory. In order to be 
geared to the changing society, the teaching evaluation system of innovation and entrepreneurship education has also been developed and improved in colleges and universities. It can get the fair evaluation in terms of the students' innovation and entrepreneurship ability in many ways, showing the problems of students and the inadequacies of teachers in teaching timely. As the most intuitive data basis for teaching and student evaluation, teaching evaluation system is shown in terms of importance as follows:

\subsection{Examine the Students' Comprehensive Level publicly}

At present, education is powered constantly by the education reform with the attention to the cultivation of high-quality talents with innovation and entrepreneurship. This trend has become much more obvious in the visual communication design major with strong application and practicality. On the one hand, teaching evaluation system can point out the direction of their own progress for students, making students know what quantitative indicators can be available to promote their own progress. Meanwhile, it is an objective evaluation of their own achievements; On the other hand, it can provide the judging criteria to evaluate students' scores. The same criteria system makes the scores relatively fair, which is conducive to the further development of innovation and entrepreneurship.

\subsection{Promote Compatibility of the University Development with Social Needs}

With the rapid development of society, the society becomes more and more competitive with higher demands for graduates. Nowadays, the graduates fostered by the higher education system have not been adapted to the development of social market economy in some aspects. It is the inadaptation and incompatibility that cause some students without work for a long time. In order to disclose the problems of students in the innovation and entrepreneurship education, the teaching evaluation system developed for improving innovation and entrepreneurship ability and consciousness of graduates forms an adjustment made by colleges and universities in the face of social changes. At the same time, this adjustment in turn can promote the progress of colleges and universities. On the other hand, the society can also have a more comprehensive understanding of the talent cultivation situation of colleges and universities so that it can select the talents needed according to the situation. In this process, the relationship between colleges and society will become closer and closer, which is beneficial to the development of colleges and society ${ }^{[2]}$.

\subsection{Improve the Competitiveness of Innovation and Entrepreneurship Education in Colleges and Universities}

In the visual communication design major, the development of innovation and entrepreneurship education is more like a kind of characteristic education on the basis of conventional education. For colleges and universities, we should adjust the existing talents training mode in line with the development of society after the recognization and understanding the value of cultivating innovation and entrepreneurship students. Among them, a scientific and perfect teaching evaluation system on the basis of innovation and entrepreneurship education can remind colleges and universities to make changes according to the needs of society while cultivating talents, which also helps to improve the competitiveness of innovation and entrepreneurship education in colleges and universities.

\section{THE EXISTING PROBLEMS WHILE PERFECTING TEACHING EVALUATION SYSTEM}

\subsection{The Curriculum System Needs to be Updated}

In some colleges and universities, the construction of talents system is short of the elements of innovation and entrepreneurship seriously. Influenced by the traditional teaching mode, the education curriculum system reform in colleges and universities has not been yet developed a mature and perfect talent training program concerning innovation and entrepreneurship. The talents training system in the colleges and universities is divorced from the concept of innovation and entrepreneurship education. Therefore, it is difficult to cultivate the innovative and entrepreneurial high-quality talents by improving the teaching evaluation system of visual communication design major. Under such a situation, it gives priority to consider how to integrate the discipline and professional resources in colleges and universities, and explore and establish a curriculum system in line with the cultivation of innovative and entrepreneurial people, and with their own characteristics actively [3].

\subsection{Teaching Philosophy and Methods have not been Improved}

(1) Compared with the United States, innovation and entrepreneurship education is far from enough in terms of the overall level in China. In addition, some society and colleges and universities have not got enough understanding, thus the concept of innovation and entrepreneurship education is only promoted in some society and colleges and universities. During the specific 
teaching process, teachers have not paid attention to improving their own teaching ability with the low enthusiasm, and students just accept knowledge mechanically without enough flexibility. Thus, their ability improves slowly naturally.

(2) It is not enough in respect of the construction of the teaching staff, the teaching philosophy and methods of teachers, and the investment of funds in the cultivation system of students' innovation and entrepreneurship ability in colleges and universities. Teachers are lack of practical experience in entrepreneurship without the effective combination of entrepreneurship and education, and lack enough time to study the content concerning innovation and entrepreneurship education in order to guide students to carry out innovation and entrepreneurship.

In view of the existing problems regarding teaching and teaching evaluation system, what we need to do is first paying enough attention, including the fund investment in this aspect of education, the requirements for teachers' awareness of innovation and entrepreneurship, and the update of teaching equipment in colleges and universities. It needs a lot of time and talents for the construction of innovation and entrepreneurship teaching evaluation system that needs to make continuous changes and adjustments according to the actual situation in order to achieve the desired goal. As for teachers, we should give enough time to study innovation and entrepreneurship courses. In case of some courses needing experience, teachers can invite entrepreneurs from the society to give lectures if they have not enough experience. They can explain something practical not shown in books, which is more innovative in order to stimulate students' interest.

\section{MEASURES TO IMPROVE TEACHING EVALUATION SYSTEM}

In order to ensure the teaching quality of students' innovation and entrepreneurship ability, every step should be bang-on while constructing the teaching evaluation system of students' innovation and entrepreneurship ability. The construction of teaching evaluation system should include the construction process, evaluation index, use method, result display, etc. While constructing the system, we should abide by the following principles, Scientificity: It should be supported by scientific theory and rigor logic, which achieves the organic combination of subjective and objective, and practical practice, in order to ensure the overall rigor and integrity in line with the laws of nature; Feasibility: the selected indicators should be able to be implemented concretely and practically, and the contents of the theory can be matched in the actual implementation; Comparability: it can achieve horizontal (compared with different universities in the same year) and longitudinal (compared with the same university in different years) comparison. While comparing, there is a reference in order to get an easy understanding; Comprehensive (the selected reference standards and categories should be as wide as possible, not too single- faceted). The rationalization of new innovation and entrepreneurship ability should be introduced into the existing teaching ability evaluation system that can be interpretated in terms of the overall system scientifically [4].

When evaluating the innovation and entrepreneurship ability of a university's major and college, what we need to do first is to integrate new innovation and entrepreneurship ability into the existing teaching ability evaluation system according to the actual teaching ability of teachers, and explain the whole system scientifically in the case where it still keeps the original system recognized by teachers. Based on the actual situation in different regions and colleges and universities performing different teaching methods, this paper analyzes the construction of the teaching evaluation system of innovation and entrepreneurship teaching ability in the school of art and design of Wuhan University of Technology. While designing the teaching evaluation system of innovation and entrepreneurship ability, the school of art and design of Wuhan University of Technology knows that the first thing is to determine the direction of the evaluation system from an overall perspective.

(1) In the light of the different locations of colleges and universities and the teaching resources they rely on, the goal of running a school is always to cultivate local highquality comprehensive talents with distinctive characteristics, and the college always puts the practical ability in the first place on the basis of stressing innovation and entrepreneurship education. Therefore, the college has designed a four-in-one mode of teaching, practice, evaluation and guarantee in order to construct the teaching evaluation system. This system is famous of prominent characteristics, that is, all students' ability as the first starting point and teachers' teaching evaluation as the second starting point, with the prominent main body and the clear level. A relatively complete innovation and entrepreneurship teaching evaluation system will be formed in the follow-up teaching evaluation.

(2) After the scientific and reasonable evaluation system is determined, it is followed by the selection of teaching evaluation system indicator and the discussion on the construction process. For the evaluation indicator of the system, its core depends on judging whether the innovation and entrepreneurship ability of students is improved and whether the teaching mode of teachers is efficient and reasonable. Then it is the analysis of the whole process of the professional evaluation system. Specifically speaking, it is to consider the professional teachers, and then start the classification work again. The teaching achievements of teachers are encouraged in the form of performance awards, which will make the standard of the whole evaluation system more scientific.

(3) It is the most important thing that the overall innovation and entrepreneurship teaching evaluation system has the practical feasibility. When determining the overall teaching evaluation system, it should not be too cumbersome and one-sided. Taking account of the overall comprehensive performance, teaching evaluation methods should be selected to ensure that the positive and negative 
incentives are reasonable. Combined with the requirements of relevant universities and professional title selection, teachers' teaching ability in students' innovation and entrepreneurship education and students' overall performance should be taken as the key conditions of teachers' title evaluation.

As for the innovation and entrepreneurship teaching launched in the whole college, teachers' teaching ability and concept need to be considered comprehensive, taking account of the explicit teaching achievements and the improvement of teachers' own quality. For teaching evaluation methods, the availability of data and the comprehensiveness of the evaluation process should set up clear indicators as a reference.

From the level of colleges and Universities: colleges and universities do not only serve as the main front of cultivating students' innovation and entrepreneurship ability, but also play a role of the backbone and pioneer for innovation and entrepreneurship education. Colleges and universities should first invest energy in innovation concept education, campus cultural environment, organization structure, curriculum provision, and teaching staff so that they can create a good environment suitable for students to cultivate entrepreneurial consciousness and spirit; From the perspective of society: Currently, it is in a groping stage for the innovation and entrepreneurship education in colleges and universities. We should make full use of the preferential policies and institutional support provided by the state, such as the special funds, rewards and channels provided by the state to support college students' entrepreneurship. Social enterprises will also make certain recognition and encouragement. They can sign entrepreneurship cooperation agreements with colleges and universities to provide the platform and entrepreneurial opportunities for the university students; Starting from the students themselves: Firstly, the task of top priority is to construct the students' psychological quality. Secondly, colleges and universities should make students' achievements public, setting with corresponding incentive mechanism. The awards can be set up to divide into the first prize, the second prize and the third prize with different awarding conditions. The excellent performance of students in colleges and universities can also be considered as the direct competitiveness in the future work, which can not only ensure the students' innovation and entrepreneurship ability, but also mobilize the students' enthusiasm

\section{CONCLUSION}

With the development of education reform, the value and importance of innovation and entrepreneurship education are more and more widely accepted with the continuous efforts of all educators. Colleges and universities have constantly brought forth new ideas and carried out practice, improving the overall quality of innovation and entrepreneurship teaching constantly. The cultivation of innovative and entrepreneurial talents is a complex and systematic work with high input, every step of which is crucial. As for the visual communication major, we need to keep pace with the times in order to cultivate innovative and entrepreneurial high-quality comprehensive talents. According to the needs of society, we need to design a set of scientific, reasonable, mature, perfect and fair teaching evaluation system based on innovation and entrepreneurship education, so as to evaluate the level of students' comprehensive innovation and entrepreneurship quality and reflect the problems existing in teaching timely. In practice, we should constantly adjust and improve the teaching evaluation system to improve its practicability and scientificity.

\section{REFERENCES}

[1] Haoran LIU. Exploring the construction of teaching evaluation system of visual communication design major based on the cultivation of students' innovation and entrepreneurship ability $[\mathrm{J}]$. Think-Tank Times. 2019 (36): $227+230$.

[2] Song LI and Jingyi HUANG. Research on the practical difficulties and countermeasures of college students' innovation and entrepreneurship education [J]. Journal of Hubei Institute of Adult Education, 2016, 22 (05): 53-55.

[3] Peng WANG. Cultural construction and mechanism innovation of university innovation and

Entrepreneurship Education [J]. Theoretical research and practice of innovation and entrepreneurship, 2019, 2 (05): 106-107.

[4] Haokai CHEN and Pinglei XU. Research on the quality evaluation indicator system of entrepreneurship education [J]. Art \& Design Research, 2007.

[5] Lingling CUI, Mengxin HE, Lin SHAO. Research on teaching evaluation system of innovation and entrepreneurship curriculum in higher vocational colleges [J]. Theoretical research and practice of innovation and entrepreneurship, 2019, 2 (1): 45-46.

[6] Chunmei ZHOU. Teaching reform of higher vocational colleges based on the cultivation of students' innovation and entrepreneurship ability [J]. Journal of Guangxi Normal University of science and technology, 2018, 33 (5): 86-88+96.

[7] Dongling FANG and Xin LI. Analysis on the "fivein-one" innovation and entrepreneurship education reform of local universities $[\mathrm{J}]$. Journal of Anhui Agricultural University (Social Science Edition), 2017, 26, (3): 110-114

[8] Rui LI and Yang CAO. Research on improving college students' employability through entrepreneurship education [J]. Modern education science, 2013, (5) 